SÉRIE „Právní a organizační základy veřejné správy“

https://doi.org/10.52058/2695-1592-2021-2(2)-156-169

\title{
Діана Бондаренко
}

магістр державного управління, заступник начальника управління з питань сочіальних відносин управління соиіального захисту населення адміністрації

Слобідського району Харківської міської ради, м. Харків, Україна, e-mail:komint_trud_77@ukr.net, https//orcid.org 0000-0001-8970-1433

\section{ДЕРЖАВНО-ПРИВАТНЕ ПАРТНЕРСТВО В СФЕРІ ІНФОРМАЦІЙНИХ ТЕХНОЛОГІЙ ЯК ІНСТРУМЕНТ РЕАЛІЗАЦЇ̈ ПОЛІТИКИ ЗАЙНЯТОСТІ МОЛОДІ (НА ПРИКЛАДІ ХАРКІВСЬКОЇ ОБЛАСТІ)}

Анотація. У статті обгрунтовано пріоритетні напрями упровадження державно-приватного партнерства (ДПП) як інструменту реалізації регіональної політики зайнятості молоді. З'ясовано, що український ринок праці представлений невеликим кількісним та якісним складом пропозицій робочих місць для молоді; а також, що вирішення проблем у сфері зайнятості молоді залежить від налагодження інституціональної взаємодії між державними та публічними секторами.

Представлено алгоритм розробки та реалізації ДПП, що містить чотири етапи. Доведено необхідність створення національної інформаційнокомунікаційної інфраструктури, яка заснована на системі взаємопов'язаних високошвидкісних комунікаційних каналах.

Визначено пріоритетні умови реалізації ДПП та соціально-значущі інфраструктурні проекти, які сприяють зайнятості молоді в Харківській області. Із врахуванням регіональних особливостей, зокрема, лідерства в Україні за кількістю IT-компаній, запропоновано використання ДПП у сфері інформаційних технологій для забезпечення зайнятості молоді в Харківській області. Розраховано, що використання державно-приватного партнерства у сфері інформаційних технологій призведе до створення 10-14 млн. нових робочих місць в Україні, у т.ч. в Харківській області - до 1,5 млн.

Розроблена концептуальна схема державно-приватного партнерства як ефективного інструменту реалізації регіональної політики зайнятості молоді в Харківській області.

Передбачено, що розвиток інформаційного простору Харківської області можливий у рамках реалізації Програми інформатизації Харківської області «Електронна Харківщина» на 2021-2023 роки. Обгрунтовано, що створення мережі оптоволоконного широкосмугового доступу до Інтернету можливо 
прискорити завдяки використанню ДПП, де державним партнером виступатиме Харківська обласна державна адміністрація, приватним - IT кампанія. Успішність використання державно-приватного партнерства значною мірою визначатиметься активністю органів державного управління у залученні приватного сектору. Доведено, що ДПП сприятиме підвищенню ефективності регіональної політики зайнятості молоді.

Ключові слова: регіональна політика зайнятості молоді, державно-приватне партнерство, інформаційні технології, молодіжний сектор праці, Харківська область.

\section{Diana Bondarenko}

master of Public Administration, Deputy Head of the Department for Social Relations of the Department of Social Protection of the Population of the Slobidsky District Administration of the Kharkiv City Council, Kharkiv,Ukraine,e-mail:komint_trud_77@ukr.net, https//orcid.org 0000-0001-8970-1433

\section{PUBLIC-PRIVATE PARTNERSHIPIN THE FIELD OF INFORMATION TECHNOLOGIES AS A TOOL FOR THE IMPLEMENTATION OF YOUTH EMPLOYMENT POLICY (ON THE EXAMPLE OF KHARKIV REGION)}

Abstract. The article substantiates the priority areas of public-private partnership (PPP) implementation as a tool for implementing regional youth employment policy. It was found that the Ukrainian labor market is represented by a small quantitative and qualitative composition of job offers for young people; and that solving problems in the field of youth employment depends on establishing institutional interaction between the public and public sectors.

An algorithm for the development and implementation of PPP, which contains four stages, is presented. The necessity of creating a national information and communication infrastructure, which is based on a system of interconnected high-speed communication channels, is proved.

Priority conditions for the implementation of PPP and socially significant infrastructure projects that promote youth employment in Kharkiv region have been identified. Taking into account regional peculiarities, in particular, the leadership in Ukraine in the number of IT companies, it is proposed to use PPP in the field of information technology to ensure youth employment in Kharkiv region. It is estimated that the use of public-private partnerships in the field of information technology will create 10-14 million new jobs, including in the Kharkiv region - up to 1.5 million.

A conceptual scheme of public-private partnership as an effective tool for implementing regional youth employment policy in Kharkiv region has been developed.

It is envisaged that the development of the information space of Kharkiv region is possible within the framework of the implementation of the Program of informatization 
of Kharkiv region "Electronic Kharkiv region" for 2021-2023. It is substantiated that the creation of a network of fiber-optic broadband Internet access can be accelerated through the use of PPP, where the state partner will be the Kharkiv Regional State Administration, the private - IT campaign. The success of the use of public-private partnerships will be largely determined by the activity of public administration bodies in involving the private sector. It has been proven that PPP will help increase the effectiveness of regional youth employment policy.

Keywords: regional policy youth employment, public-private partnership, information technologies, youth labor sector, Kharkiv region.

Постановка проблеми. Інтеграція України в європейський простір має супроводжуватися трансформацією соціально-економічних відносин. Разом із тим, на сьогодні ринок праці представлений невеликим кількісним та якісним складом пропозицій робочих місць для молоді. Це відбувається через неврахування регіональних особливостей молодіжного сегменту ринку праці, невідповідність освітніх програм закладів освіти існуючим пропозиціям робочих місць у регіонах за різними секторами економіки. Неефективна державна політика зайнятості молоді призводить до структурного дисбалансу між пропозицією та попитом на ринку праці, а в подальшому - до погіршення якості трудового потенціалу і унеможливлює забезпечення динамічного економічного зростання в регіонах країни. Невирішеність проблем у сфері зайнятості молоді $\epsilon$ першопричиною ii відтоку за кордон. Виникає потреба перегляду й оновлення молодіжного сегменту ринку праці, що обумовлює необхідність удосконалення державної політики зайнятості молоді на регіональному рівні.

Для здійснення контролю за дотриманням законодавства про працю, зокрема, стосовно молоді, Міністерством соціальної політики України впроваджуються заходи, спрямовані на детінізацію відносин у сфері зайнятості населення якими передбачається проведення комплексних заходів, спрямованих на детінізацію зайнятості молоді [1]. Розроблений проєкт Закону України «Про внесення змін до деяких законодавчих актів України щодо посилення захисту прав працівників та протидії застосуванню незадекларованої праці», яким пропонується, зокрема, визначити поняття, ознаки наявності трудових відносин, встановити принцип презумпції наявності трудових відносин. В Україні існує доволі значний спектр законодавчих ініціатив і нормативно-правових актів щодо забезпечення гідної праці молоді. Проте ефективність реалізації заходів державної політики у сфері молодіжної зайнятості залишається недостатньо високою та потребує подальшого вдосконалення.

Статистичні дані про заплановане масове вивільнення працівників у зв’язку зі змінами в організації виробництва і праці, які на червень 2021 року в Харківській області склало 93711 осіб, (з них 73 \% молодь) що на 5360 осіб більше, порівняно 3 червнем 2020 року [2], підтверджують нагальність упровадження такого інноваційно-інвестиційного інструменту державної політики зайнятості молоді, як державно-приватне партнерство(ДПП). Тим більше, що Харківська область за чисельністю населення посідає 3-е місце в Україні, а питома вага молоді у віковій структурі населення регіону складає $35 \%$. 
Використання ДПП пов'язано 3 неспроможністю учасників державного сектора через відсутність необхідних бюджетних коштів та інших ресурсів забезпечити реалізацію вкрай важливих проєктів, які направлені на соціально-економічний розвиток регіонів. Це обумовлює актуальність зазначеної теми дослідження.

Аналіз останніх досліджень та публікацій. Особливу увагу дослідженню проблем розвитку державно-приватного партнерства, формування ефективної міжсекторної взаємодії приділили такі вітчизняні та зарубіжні вчені, як: I. Брайловський, М. Возняк, І. Дробот, Д. Делмон, Р. Жишко, С. Сгоричев, В. Варнавский, Т. Сфименко, Г. Комарницька, В. Круглов, М. Лахижа, М. Масик, А. Павлюк， І. Турчак， С. Сімак，О. Сімсон，О. Солодовнік， І. Чукаєв， Г. Ходж， П. Шилепницький та ін. Проте поліаспектність та багатовекторність розвитку та використання державно-приватного партнерства, а також нові завдання соціально-економічного розвитку регіонів висувають нові питання, що і створює підгрунтя для подальших розробок. Залишаються не дослідженими питання щодо обгрунтування пріоритетної сфери застосування ДПП у регіонах, зокрема Харківському, з метою вирішення питань зайнятості молоді.

Теоретико-методологічною основою дослідження $\epsilon$ наукові праці вітчизняних і зарубіжних вчених 3 державного управління. Для вирішення поставлених задач були застосовані системно-логічний метод та порівняльний аналіз для обгрунтування пріоритетної сфери упровадження державноприватного партнерства як інструменту реалізації регіональної політики зайнятості молоді в Харківській області; а також графічний метод - для схематичної візуалізації основних теоретичних i практичних положень дослідження; метод узагальнення - для формулювання висновків.

Метою дослідження $є$ обгрунтування необхідності використання державноприватного партнерства в сфері інформаційних технологій як інструменту реалізації політики зайнятості молоді в Харківській області.

Для досягнення мети необхідним є вирішення наукових завдань:

обгрунтування напрямів упровадження державно-приватного партнерства як інструменту реалізації регіональної політики зайнятості молоді;

визначити пріоритетні умови реалізації ДПП та сфери зайнятості молоді в Харківській області;

запропонувати концептуальну схему реалізації державно-приватного партнерства з метою забезпечення зайнятості молоді на регіональному рівні.

Виклад основного матеріалу. На сьогодні державно-приватне партнерство успішно реалізовано в різних секторах України, а саме мають місце окремі спроби залучення бізнесу до розвитку телекомунікаційного, енергетичного секторів, секторів інфраструктури, освіти. Як свідчить аналітична оцінка розвитку державно-приватного партнерства, найбільше договорів укладено в сектор i розбудови інфраструктури, на другому місці - інформаційнокомунікаційні технології. Так, серед десяти проектів державно-приватного партнерства із найвищим рівнем інвестицій вісім реалізуються в енергетичному секторі, останні два проекти - у секторі інформаційно-комунікаційних технологій та транспорті (порти). 
Упровадження державно-приватного партнерства є важливим інструментом реалізації регіональної політики зайнятості молоді, а також отримання соціального ефекту в країні. Існують сфери, де приватний сектор володіє більшим досвідом в реалізації проектів, які мають соціальний ефект, тому у держави є потреба в укладенні відповідних контрактів із ним. Великий потенціал у розвитку партнерських відносин із приватним бізнесом у своєму розпорядженні має місцева влада, яка реалізує свої програми соціально-економічного розвитку 3 урахуванням особливостей конкретного регіону. Державно-приватне партнерство створює підгрунтя для реалізації інфраструктурних інвестиційних проектів, що сприяє підвищенню конкурентоспроможності на регіональному та загальнодержавному рівнях.

Основний нормативно-правовий акт, що регулює діяльність у сфері державно-приватного партнерства $є$ Закон України, згідно 3 яким державноприватне партнерство - співробітництво між державою Україна, Автономною Республікою Крим, територіальними громадами в особі відповідних державних органів, та органів місцевого самоврядування (державними партнерами) та юридичними особами, крім державних i комунальних підприємств, або фізичними особами - підприємцями (приватними партнерами), що здійснюється на основі договору в порядку, встановленому Законом та іншими законодавчими актами [3, ст. 1].

У науковій літературі містяться безліч сучасних підходів щодо сутності визначення поняття державно-приватного партнерства. Використовується п'ять ключових визначень ДПП: інноваційний інструмент, угода, система відносин, бізнес-модель взаємодії, співробітництво. 3'ясовано, що частіше науковці визначають ДПП як співробітництво між державним та приватним секторами, що побудовані на досвіді кожного 3 учасників партнерства 3 метою задоволення соціально-значущих потреб[4].

Організація Економічного Співробітництва та Розвитку визначає таке партнерство між публічним та приватним секторами як угоду між урядом та одним або декількома приватними партнерами (до яких можуть входити оператори та фінансисти), згідно 3 якою приватні партнери надають послугу таким чином, щоб державні цілі надання публічних послуг були узгоджені 3 цілями отримання прибутку приватними партнерами. Ефективність такого узгодження залежить від належної передачі ризику приватним партнерам [5]. О. Сімсон зазначив, що ДПП - це інструмент гармонізації публічних і приватних інтересів в інноваційній стратегії України [6].

Згідно з визначенням Свропейської економічної комісії ООН державноприватне партнерство $є$ інноваційним методом, що використовується публічнім сектором для укладання договорів з приватним сектором. Останній привносить свій капітал та здатний реалізовувати проекти у визначений час та відповідно до бюджету, тоді як публічний сектор зберігає відповідальність за надання цих послуг громадськості, забезпечуючи економічний розвиток та поліпшення якості[7].

У розумінні Е. Уайт, Б. Дезілец, О. Маслюківської, Ю. Шевчук партнерство державного і приватного секторів означає таку форму співпраці між державними 
органами влади та бізнесом, що має на меті забезпечити фінансування, будівництво, відновлення, управління або утримання інфраструктури чи надання суспільних послуг. Мета партнерства полягає в поєднанні найкращих аспектів державного та приватного секторів для спільної вигоди, а різноманіття видів, форм и сфер застосування державно-приватного партнерства роблять його універсальним механізмом для вирішення низки довгострокових задач - від створення та розвитку інфраструктури до розробки та адаптації нових перспективних технологій [8].

Державно-приватне партнерство,утворюючи синергетичність партнерства, забезпечує ефективне використання трудового, інноваційного, ресурсного потенціалів. 3 метою зменшення диспропорцій між попитом та пропозиціями на ринку праці важливим $є$ налагодження інституціональної взаємодії між державними та публічними секторами, яка може здійснюватися за такими напрямками:

- функціональний напрям передбачає розвиток державно-приватного партнерства у сферах, які визначають доступ приватного сектора до факторів виробництва і ринків професійної освіти, технологій, капіталу;

- галузевий напрям передбачає розроблення галузевих планів розвитку державно-приватного партнерства на основі секторальної ідентифікації напрямів зростання і стримуючих це зростання перешкод, аналізу і розроблення заходів i пріоритетів щодо покращення бізнес-середовища в конкретних секторах економіки;

- регіональний напрям передбачає розроблення регіональних планів розвитку державно-приватного партнерства, окремих територіальних кластерів;

- організаційні заходи, що забезпечують успішність інституціональної взаємодії держави і бізнесу:цілеспрямована інформаційно-аналітична підтримка, моніторинг i розповсюдження кращої практики діяльності об'єднань роботодавців і органів виконавчої влади для підвищення конкурентоспроможності економіки регіону[9].

Важливими партнерами держави у сфері реалізації державної політики зайнятості молоді $є$ роботодавці, саме вони створюють нові робочі місця для молоді, приймають на роботу молодих працівників, забезпечують центри зайнятості інформацією щодо власних потреб у робочій силі, сплачують податки і страхові внески, чим забезпечують реалізацію державних соціальних гарантій. Оскільки роботодавці є невід'ємними суб'єктами ринку праці, від діяльності яких залежить рівень працевлаштування молоді, співпраця з ними є безпосередньою умовою ефективного функціонування молодіжного сегменту ринку праці. Забезпечення ефективності такої взаємодії можливе за умови врахування інтересів роботодавців та їхнього усвідомлення необхідності активної участі у процесі підготовки молодих фахівців [10 ].

За підтримки проекту Світового банку Міністерство економіки України розробило низку підзаконних актів щодо забезпечення прозорості процесу відбору приватного партнера, методичні рекомендації для ініціаторів проектів щодо реалізації регіональної політики зайнятості молоді (рис 1). 


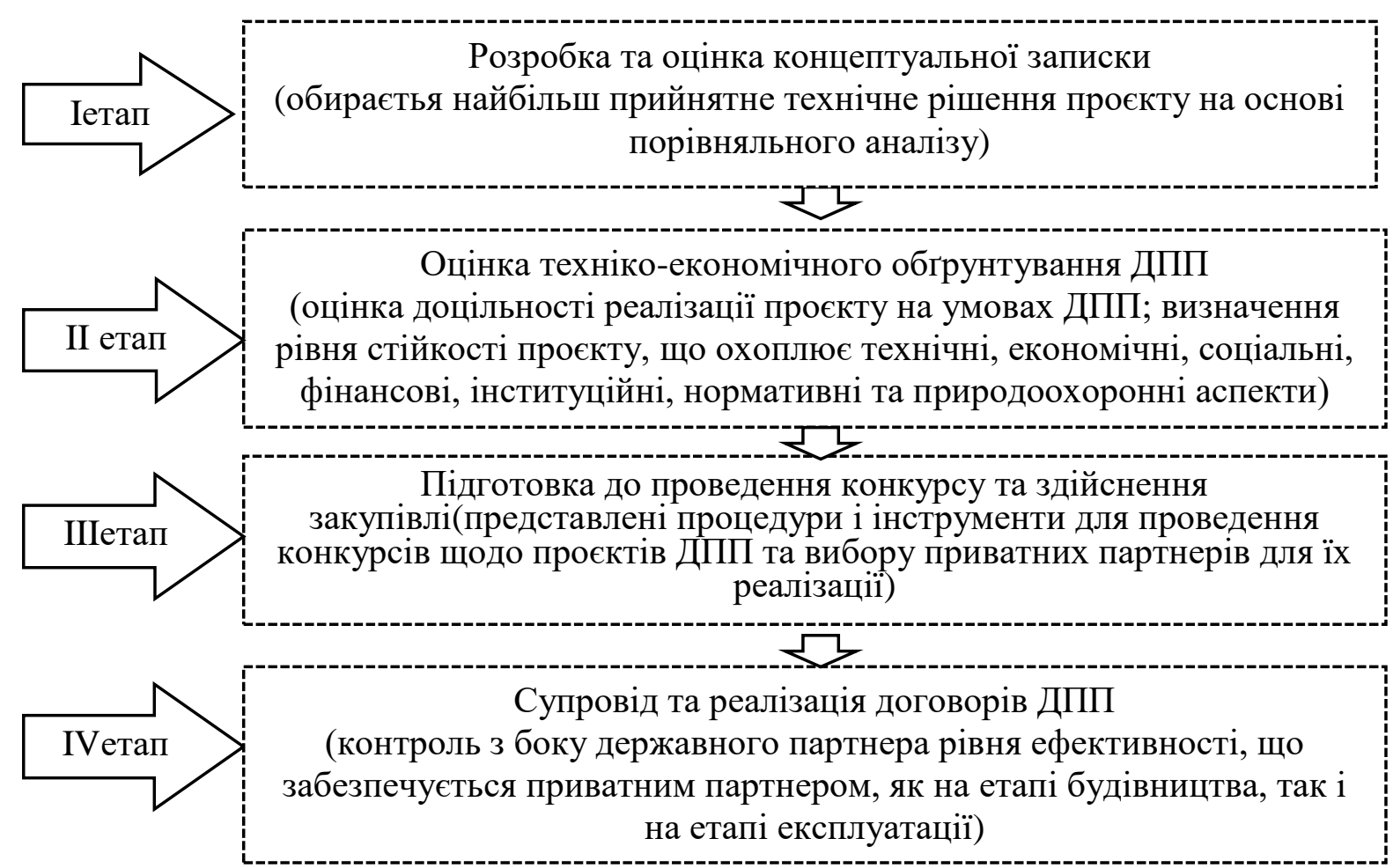

Рис. 1. Алгоритм розробки та реалізації державно-приватного партнерства [Узагальнено на основі12]

Державно-приватне партнерство дозволяє реалізувати пріоритетні та соціально-значущі інфраструктурні проекти, а також сприяє покращенню бізнесклімату в регіонах Україні. Одним із пріоритетних умов реалізації державноприватного партнерства є формування єдиного інформаційного простору країни. Для цього необхідним $є$ створення національної інформаційно-комунікаційної інфраструктури, яка заснована на системі взаємопов'язаних високошвидкісних комунікаційних каналах. Темпи розвитку інформаційно-комунікаційних технологій пов'язані з доступністю ресурсів мережі Інтернет.

У постанові ВРУ від 31.03.2016 № 1073-VIII «Рекомендації парламентських слухань на тему: «Реформи галузі інформаційно-комунікаційних технологій та розвиток інформаційного простору України» зазначено, що інформаційнокомунікаційні технології (далі - IКТ) є одним із найбільш важливих чинників стимулювання економічного зростання та розвитку громадянського суспільства, зайнятості молоді, розширення конкуренції i, як наслідок, сприяння подоланню «цифрового розриву» [11].

Варто відзначити, що Україна належить до числа країн, в яких на законодавчому рівні розвиток інформаційного суспільства та впровадження новітніх ІКТ в усі сфери суспільного життя і в діяльність органів державної влади та органів місцевого самоврядування визначається одним 3 пріоритетних напрямків державної політики.

У національному законодавстві також задекларована підтримка Україною засад, завдань та цілей, проголошених у документах, прийнятих на Женевському (2003 р.) та Туніському (2005 р.) самітах 3 питань інформаційного суспільства, а також ії готовність брати участь у глобальному процесі формування «відкритого 
для всіх і спрямованого на розвиток інформаційного суспільства» [13]. 3 метою визначення напрямів, механізмів і строків формування ефективної системи електронного урядування в Україні для задоволення інтересів та потреб фізичних та юридичних осіб, вдосконалення системи державного управління, підвищення конкурентоспроможності та стимулювання соціально-економічного розвитку країни, розпорядженням Кабінету Міністрів України від 09 вересня 2017 року № 649-р схвалено Концепцію розвитку електронного урядування в Україні [14].

Сучасні інформаційно-комунікаційні технологіі вагомо змінюють наше життя, а саме: спосіб виробництва продуктів і послуг, організацію та форми зайнятості населення, зокрема молоді. Враховуючи залежність інформаційнокомунікаційних технологій від доступності ресурсів мережі Інтернет та всіх пов'язаних 3 нею сервісів, надійності та стабільності підключення до неї та дедалі зростаючих швидкостях, зазначимо їх вплив на розвиток соціокультурних інститутів, соціальну структуру суспільства, наявність якісного потенціалу зайнятого населення в країні.

Від стратегічної можливості постійної модернізації під'єднань до мережі залежатиме конкурентоспроможність держави в новому цифровому світі. Йдеться передусім про широкосмуговий доступ (ШСД)до Інтернету як центральний елемент сучасної інформаційної інфраструктури. На сьогодні більшість інформаційно розвинених держав світу приділяють увагу національним інфраструктурним проектам, які пов'язані із забезпеченням громадян доступним, якісним ШСД до Інтернету.

Слід зауважити, що сьогодні ситуація з розвитком широкосмугового доступу до Інтернету в Україні характеризується певною неоднозначністю. Проведений у 2020 році Міністерством цифрової трансформації аналіз стану доступу населення до високошвидкісного фіксованого Інтернету свідчить про значні прогалини в техніко-технологічному забезпеченні регіонів країни. Незважаючи на те, що загальний показник кількості абонентів у регіонах країни зростає, рівень якісного та швидкісного Інтернету із ШСД залишається доволі низьким, особливо, якщо це стосується обласних центрів регіонів: тільки 35\% населених пунктів країни покрити якісним ШСД. Згідно 3 Національною стратегію розвитку широкосмугового доступу до Інтернету до 2024 року, Міністерство цифрової трансформації розробило низку заходів, де планує 95\% регіонів країни забезпечити якісним та швидкісним Інтернетом із ШСД. До стратегії входить розробка Інтернет-платформи, за допомогою якої можливим стане якісна взаємодія 3 державними органами в електронному вигляді, прозорі умови доступу до інфраструктури, мінімізація втрат операторів від крадіжок обладнання, «відкритість» усіх стейкхолдерів телеком ринку та фінансування підключення закладів соціальної інфраструктури [15].

У Програмі інформатизації Харківської області «Електронна Харківщина» на 2018-2020 роки, пріоритетним завданням якої були розбудова волоконнооптичної кабельної системи, модернізація існуючої структурованої кабельної системи та комунікаційного вузла Харківської обласної ради та обласної державної адміністрації, бюджетних установ Харківської області [17]. 3 метою забезпечення формування та виконання Програми розпорядженням голови 
Харківської обласної державної адміністрації «Про розроблення Програми інформатизації Харківської області» ще у 2010 р. утворено науково-технічну раду програми інформатизації Харківської області, на яку покладено координацію робіт з інформатизації, обов'язки підготовки та відбору завдань для регіональної програми інформатизації [16].

3 метою розвитку інформаційного простору Харківської області, в рамках Програми інформатизації Харківської області «Електронна Харківщина» на 20212023 роки, до основних завдань якої зокрема віднесено побудова та підключення до волоконно-оптичних ліній зв'язку об'єктів соціальної інфраструктури (заклади охорони здоров'я, освіти, культури, спорту і т.д.) області [18] нами пропонується реалізувати проект за допомогою державно-приватного партнерства в напрямку створення мережі оптоволоконного широкосмугового доступу до Інтернету (пропускна здатність 100 мегабіт на секунду та вища). Використання моделі ДПП для створення мережі оптоволоконного широкосмугового доступу до Інтернету в Харківській області націлене на забезпечення сталого економічного розвитку та підвищення конкурентоспроможності Харківського регіону та України в цілому в сфері ІТ-послуг, забезпечення комплексного розвитку електронного урядування, відповідно до європейських вимог. Це матиме значні пріоритети для бізнесу, освіти, медицини, а також додаткові можливості у створенні елементу вузла регіонального зв'язку та використанні у подальшому Інтернет-трафіку між Східною Європою та Південним Кавказом, Європою та Центральною Азією. Це також забезпечить робочими місцями молодь Харківського регіону.

За даними статистики Харківський регіон - лідер в Україні за кількістю ITкомпаній: понад 500 IT-компаній, понад 31000 висококваліфікованих фахівців та 17 закладах вищої освіти (ЗВО) Харкова, які випускають молодих IT-фахівців. За даними Харківського обласного центру зайнятості попит на IT-фахівців у 2021 році перевищує пропозицію, тому потреба компаній у молодих IT-фахівцях у півтора рази перевищує кількість випускників. Отже, 3 метою реалізації регіональної політики зайнятості молоді та враховуючи розвиненість в Харківській області сфери IT-послуг варто розглянути в якості приватного партнера державно-приватного партнерства IT компанії (рис. 2). 


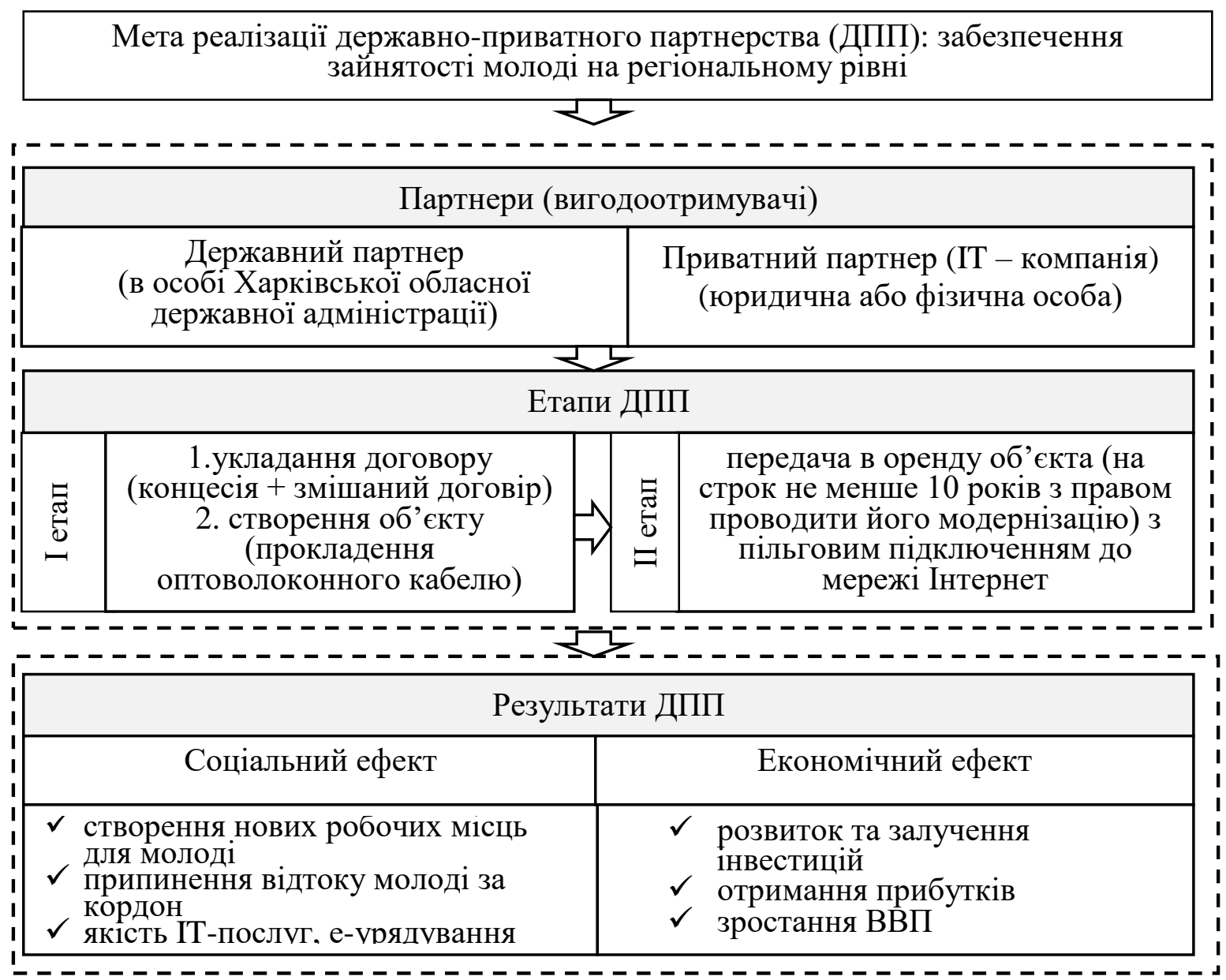

Рис. 2. Концептуальна схема реалізації державно-приватного партнерства в аспекті забезпечення зайнятості молоді в регіоні [Складено автором]

Другий етап реалізації державно-приватного партнерства, а саме передача в оренду об'єкта 3 пільговим підключенням до мережі Інтернет, має реалізовуватися 3 наданням приватному партнеру пільгового підключення до мережі Інтернет з орендною платою за користування Інтернетом на постійній основі у 30 \% за умови забезпечення першим робочим місцем молодь до 35 років. Згідно 3 аналітичними оцінками, створення мережі оптоволоконного широкосмугового доступу до Інтернету здатне створити 10-14 млн. нових робочих місць в Україні у таких галузях, як виробництво електронного обладнання та приладів, а також офшорних послугах та аутсорсингу [17]. Виходячи 3 того, що м. Харків спеціалізується, зокрема на аутсорсингу [17], враховуючи кількість ЗВО та їх випускників, а також IT-компаній у регіоні, нами розраховано, що лише по Харківській області приблизна кількість новостворених робочих місць може скласти до 1,5 млн.

Слід зауважити, що запропонована концептуальна схема державноприватного партнерства як ефективного інструменту реалізації регіональної політики зайнятості молоді в регіоні вирішує низку питань, які направлені на отримання соціального ефекту в Харківській області.

Серед переваг для державного сектору від участі у проекті ДПП приватного партнера є створення нових робочих місць для молодих фахівців із конкурентною 
заробітною платою та як наслідок збільшення податків і зборів до бюджетів та фондів усіх рівнів, припинення відтоку молодих фахівців за кордон, розвиток та залучення інвестицій, більш швидка реалізація інфраструктурних проектів за рахунок залучення коштів приватного інвестора, запозичення кращих практик управління власністю та оптимізація структури управління. Серед переваг для бізнес партнерів від участі у проекті ДПП слід виділити: розширення можливостей для отримання кредитів під проект від вітчизняних та іноземних фінансових установ на основі державних гарантій, отримання прибутку у найближчій перспективі у вигляді плати за користування мережею Інтернет на певний період часу (5-10 років), можливість першочергової модернізації мережі Інтернет, можливість здачі в оренду об'єкту ДПП (мережі Інтернет), підтримка 3 боку державних органів на всіх етапах реалізації ДПП, створення позитивного іміджу компанії.

Висновки. Державно-приватне партнерство $є$ дієвим інструментом реалізації регіональної політики зайнятості молоді, зокрема у сфері важливих інфраструктурних проектів. Використання ДПП у сфері інформаційних технологій призведе до створення 10-14 млн. нових робочих місць в Україні, у т.ч. у Харківській області - до 1,5 млн. Враховуючи, що Харківський регіон $\epsilon$ лідером в Україні за кількістю IT-компаній, використання державно-приватного партнерства в сфері інформаційних технологій сприятиме зростанню рівня зайнятості молоді в Харківській області. Подальший розвиток інституційних інструментів державно-публічного партнерства сприятиме створенню інвестиційного клімату для організації бізнесу в Харківській області, розвитку інформаційно-комунікаційної інфраструктури, зокрема, мережі оптоволоконного широкосмугового доступу до Інтернету.

Успішність проектів державно-приватного партнерства в рамках реалізації Програми інформатизації Харківської області «Електронна Харківщина» на 2021 2023 роки значною мірою визначатиметься активністю органів влади у залученні приватного сектору до інвестиційно-інноваційних проектів.

Реалізація проектів ДПП у сфері інформаційно-комунікаційних технологій сприяє зменшенню навантаження на бюджет Харківської області, збільшенню податків і зборів до регіонального бюджету, припиненню відтоку молодих ITфахівців за кордон, підвищенню ефективності регіональної політики зайнятості молоді.

\section{Лimepamypa:}

1. Про заходи, спрямовані на детінізацію відносин у сфері зайнятості населення: розпорядження Кабінету Міністрів України від 05.09.2018 № 649-p. URL: https://zakon.rada.gov.ua/laws/show/649-2018-\%D1\%80

2. Державна служба статистики.URL: http://www.ukrstat.gov.ua/.

3. Про державно-приватне партнерство: Закон України від 01.07.2010 № 2404-VI. Відомості Верховної Ради Украӥни (ВВР). 2010. № 40. Ст. 524. URL: https://zakon.rada.gov.ua/laws/show/2404-17\#Text

4. Бондаренко Д. П. Державно-приватне партнерство як інноваційний інструмент реалізації державної політики зайнятості молоді на регіональному рівні. Державне управління та місиеве самоврядування: зб. наук. пр. Дніпро : ДРІДУ НАДУ. 2020, Вип. 3(46). С. 61-68. 
URL:https://grani-print.dp.ua/index.php/dridu/issue/view/42

5. Public-Private Partnerships: In Pursuit of Risk Sharing and Value for Money. Paris: OECD. 2008.URL:https://www.oecd.org/gov/budgeting/publicprivatepartnershipsinpursuitofrisksharingandva lueformoney.htm

6. Сімсон О. Е. Правова модель державно-приватного партнерства як інструмент гармонізації публічних і приватних інтересів в інноваційній стратегії України : автореф. дис. ... д-ра юрид. наук : 12.00.04, 12.00.03 / Нац. юрид. ун- т ім. Ярослава Мудрого. Харків, 2015. 42 с.

7. Guidebook on good governance on public-private partnership. United NationsEconomic Commission for Europe. 2008. URL: https://unece.org/ru/economic-cooperation-andintegration/publications/guidebook-promoting-good-governance-public

8. Уайт Е., Дезілец Б., Маслюківська О., Шевчук Ю. Посібник з публічно-приватних партнерств /Агентство США 3 міжнародного розвитку (USAID). URL: http://www.ekmair.ukma.edu.ua/bitstream/handle/123456789/575/PPP_Guidelines_ukr_2009.pdf? sequence $=1 \&$ is Allowed $=\mathrm{y}$

9. Єфименко T.I. Черевиков С.Л., Павлюк К.В. та ін. Державно-приватне партнерство в системі регулювання економіки: монографія / за заг.ред. чл.-кор. НАНУ Т.І. Єфименко; НАН України, Ін-т екон. та прогнозув. Київ, 2012. 372с.

10. Молодь на ринку праці: навички XXI століття та побудова кар'єри. Щорічна доповідь Президентові України, Верховній Раді України, Кабінету Міністрів України про становище молоді в Україні /Держ. ін-т сімейної та молодіжної політики. Київ, 2019. 107 с. URL: https://dismp.gov.ua

11. Про Рекомендації парламентських слухань на тему: "Реформи галузі інформаційнокомунікаційних технологій та розвиток інформаційного простору України": Постанова Верховної Ради України. Відомості Верховної Ради України (ВВР). 2016. № 17. Ст. 191. URL: https://zakon.rada.gov.ua/laws/show/1073-19\#Text

12. Урядовий портал. URL: https://www.me.gov.ua/Documents/Detail?lang=ukUA\&id=2bc79196-a3b2-41a9-86e2 f55f9a8f5c9c\&title=Metodichni Rekomendatsii

13. Про Основні засади розвитку інформаційного суспільства в Україні на 2007-2015 роки: Закон України від 09.01.2007 № 537-V. URL: https://zakon.rada.gov.ua/go/537-16

14. Про схвалення Концепції розвитку електронного урядування в Україні, затверджене розпорядженням Кабінету Міністрів України від 20 вересня 2017 р. № 649-p. Київ. URL: https://zakon.rada.gov.ua/laws/show/649-2017-\%D1\%80\#Text

15. Міністерство цифрової трансформації. URL: https://thedigital.gov.ua/regulations/ povidomlennya-pro-provedennya-publichnogo-gromadskogo-obgovorennya-proyektu-nacionalnoyistrategiyi-rozvitku-shirokosmugovogo-dostupu-do-internetu?fbclid=IwAR3dqZxg2X6oVbCqRKnenLCTQ5ZawsAUn-MC-GWofPQxb0InFgCbJEuxg4

16. Про розроблення Програми інформатизації Харківської області (зі змінами) : Розпорядження голови Харківської обласної державної адміністрації від 26 травня 2010 року №267. URL: https://kharkivoda.gov.ua/dokumenti/rozporyadzhennya/2141/2149/43379

17. Програма інформатизації Харківської області «Електронна Харківщина» на 2018-2020 роки. URL: http://www.oblrada.kharkov.ua/ua/public-information/oblasni-programi/322-prohramainformatyzatsii-kharkivskoi-oblasti-elektronna-kharkivshchyna-na-2018-2020-roky

18. Програма інформатизації Харківської області «Електронна Харківщина» на 2021-2023 роки: Затверджено Розпорядженням голови обласної державної адміністрації від 05.02.2021р. № 43. URL : https://ts.lica.com.ua/?type=1\&base=77\&menu=378998\&id=18924

\section{References:}

1. Pro zakhody, spryamovani na detinizatsiyuvidnosyn u sferi zaynyatostinaselennya: rozporyadzhennya Kabinetu Ministriv Ukrayiny vid 05.09.2018 № 649-r. [Elektronnyy resurs]. Rezhym dostupu: https://zakon.rada.gov.ua/laws/show/649-2018-\%D1\%80 
2. Derzhavnasluzhbastatystyky

[Elektronnyy

resurs].

Rezhym

dostupu:http://www.ukrstat.gov.ua/.

3. Zakon Ukrayiny «Pro derzhavno-pryvatnepartnerstvo» (VidomostiVerkhovnoyi Rady Ukrayiny (VVR), 2010, № 40, st.524) [Elektronnyy resurs]. - Rezhym dostupu: https://zakon.rada.gov.ua/laws/show/2404-17\#Text

4. Bondarenko D. P. Derzhavno-pryvatnepartnerstvo yak innovatsiynyyinstrument realizatsiyi derzhavnoyi politykyzaynyatostimolodi na rehional'nomu rivni. Zbirnyknaukovykh prats' «Derzhavne upravlinnya ta mistsevesamovryaduvannya»:zb. nauk. pr. - Dnipro : DRIDU NADU. - 2020, Vyp. 3(46). - S.61-68. - Rezhym dostupu: https://grani-print.dp.ua/index.php/dridu/issue/view/42

5. Public-Private Partnerships: In Pursuit of Risk Sharing and Value for Money. Nadayut'syaParis: OECD. - 2008. - R. 12 [Elektronnyy resurs]. - Rezhym dostupu: https://www.oecd.org/gov/budgeting/publicprivatepartnershipsinpursuitofrisksharingandvalueformoney.htm

6. Simson O. E. Pravovamodel' derzhavno-pryvatnohopartnerstva yak instrumentharmonizatsiyipublichnykh i pryvatnykhinteresiv $\mathrm{v}$ innovatsiyniystratehiyi Ukrayiny : avtoref. dys. ... d-ra yuryd. nauk : 12.00.04, 12.00.03 / O. E. Simson ; Nats. yuryd. un- t im. YaroslavaMudroho. - Kharkiv, 2015. - 42 s.

7. Guidebook on good governance on public- private partnership. United Nations Economic Commission for Europe. - 2008. - R. 1 [Elektronnyy resurs]. - Rezhym dostupu: https://unece.org/ru/economic-cooperation-and-integration/publications/guidebook-promoting-goodgovernance-public

8. Uayt E. Posibnyk $\mathrm{z}$ publichno-pryvatnykhpartnerstv [Elektronnyy resurs] /E. Uayt, B. Dezilets, O. Maslyukivs'ka, YU.Shevchuk.- - Ahent.stvo SSHA z mizhnarodnoho rozvytku (USAID).- Rezhym dostupu: http://www.ekmair.ukma.edu.ua/bitstream/handle/123456789/575/PPP Guidelines_ukr_2009. pdf? sequence $=1 \&$ is Allowed=y

9. Yefymenko T.I. Cherevykov YE.L., Pavlyuk K.V. ta in. Derzhavno-pryvatnepartnerstvo v systemirehulyuvannyaekonomiky / T.I. Yefymenko, YE.L. Cherevykov, K.V. Pavlyuk ta in. monohrafiya zazah.red. chl.-kor. NANU T.I. Yefymenko/ NAN Ukrayiny, In-t ekon. ta prohnozuv. K. $-2012 .-372$ s.

10. Molod' na rynkupratsi: navychky XXI stolittya ta pobudovakar"yery. Shchorichnadopovid' Prezydentovi Ukrayiny, VerkhovniyRadi Ukrayiny, KabinetuMinistriv Ukrayiny prostanovyshchemolodi v Ukrayini /Derzh. in-t simeynoyi ta molodizhnoyipolityky. - Kyyiv. - 2019. - 107 s. [Elektronnyy resurs]. - Rezhym dostupu:https://dismp.gov.ua

11. PostanovaVerkhovnoyi Rady Ukrayiny Pro Rekomendatsiyiparlament·s'kykhslukhan' na temu: "Reformyhaluziinformatsiyno-komunikatsiynykhtekhnolohiy ta rozvytokinformatsiynohoprostoru Ukrayiny" (VidomostiVerkhovnoyi Rady (VVR), 2016, № 17, st.191) [Elektronnyy resurs]. Rezhym dostupu: https://zakon.rada.gov.ua/laws/show/1073-19\#Text

12. Uryadovyyportal [Elektronnyy resurs]. - Rezhym dostupu: https://www.me.gov.ua/ Documents/Detail?lang=uk-UA\&id=2bc79196-a3b2-41a9-86e2

f55f9a8f5c9c\&title=MetodichniRekomendatsii

13. Pro Osnovni zasady rozvytku informatsiynohosuspil'stva v Ukrayini na 2007-2015 roky: Zakon Ukrayiny vid 09.01.2007 № 537-V[Elektronnyy resurs]. - Rezhym dostupu: https://zakon.rada.gov.ua/go/537-16

14. Pro skhvalennyaKontseptsiyi rozvytku elektronnohouryaduvannya v Ukrayini, zatverdzhenerozporyadzhennyamKabinetuMinistriv Ukrayiny vid 20 veresnya 2017 r. № 649-r. Kyyiv[Elektronnyy resurs]. - Rezhym dostupu:https://zakon.rada.gov.ua/laws/show/649-2017$\%$ D1\%80\#Text

15. Ministerstvotsyfrovoyi transformatsiyi [Elektronnyy resurs]. - Rezhym dostupu: https://thedigital.gov.ua/regulations/povidomlennya-pro-provedennya-publichnogo-gromadskogoobgovorennya-proyektu-nacionalnoyi-strategiyi-rozvitku-shirokosmugovogo-dostupu-do-internetu? fbclid=IwAR3dqZxg2X6oVbCqRK-nenLCTQ5ZawsAUn-MC-GWofPQxb0InFgCbJEuxg4 
16. Rozporyadzhennya vid 26 travnya 2010 roku №267 "Pro rozroblennyaProhramy informatyzatsiyi Kharkivs'koyi oblasti" (zizminamy) [Elektronnyy resurs]. - Rezhym dostupu:https://kharkivoda.gov.ua/dokumenti/rozporyadzhennya/2141/2149/43379

17. Prohrama informatyzatsiyi Kharkivs'koyi oblasti «Elektronna Kharkivshchyna» na 2018 2020 roky [Elektronnyy resurs]. - Rezhym dostupu:

http://www.oblrada.kharkov.ua/ua/public-information/oblasni-programi/322-prohrama-

informatyzatsii-kharkivskoi-oblasti-elektronna-kharkivshchyna-na-2018-2020-roky

18. Programa informatizaciï Harkivs'koï oblasti «Elektronna Harkivshhina» na 2021-2023 roki: Zatverdzheno Rozporjadzhennjam golovi oblasnoï derzhavnoï administraciï vid 05.02.2021 r. № 43. URL : https://ts.lica.com.ua/?type=1\&base=77\&menu=378998\&id=18924 